\begin{tabular}{|c|c|c|}
\hline 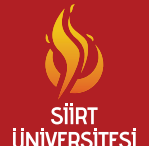 & $\begin{array}{c}\text { Türkiye Tarımsal Araştırmalar Dergisi } \\
\text { dergipark.org.tr/tutad }\end{array}$ & $\begin{array}{l}\text { Turk J Agric Res } \\
\text { 2021, 8(3): 345-351 } \\
\text { ○) TÜTAD } \\
\text { ISSN: 2148-2306 } \\
\text { e-ISSN: 2528-858X }\end{array}$ \\
\hline Bilimin Psüunda & Araştırma Makalesi / Research Article & doi: $10.19159 /$ tutad.998869 \\
\hline
\end{tabular}

\title{
Hububat Ekiliş Alanlarında Süne Eurygaster spp.'nin Yumurta Parazitoiti, Trissolcus (Hymenoptera: Scelionidae) Türleri Üzerinde Çalışmalar: Iğdır, Ağrı ve Van İlleri, Türkiye*
}

\author{
Mustafa AÇIKGÖZ ${ }^{\text {1**}}$, Celalettin GÖZÜAÇIK ${ }^{2}$ \\ ${ }^{1}$ Kahramanmaraş Sütçü İmam Üniversitesi, Ziraat Fakültesi, Bitki Koruma Bölümü, Kahramanmaraş, TÜRKİYE \\ ${ }^{2}$ Iğdır Üniversitesi, Ziraat Fakültesi, Bitki Koruma Bölümü, Iğdır, TÜRKIYE
}

\begin{tabular}{ll}
\hline \multicolumn{1}{c}{ Geliş Tarihi/Received: 23.09 .2021} & Kabul Tarihi/Accepted: 27.11 .2021 \\
\hline ORCID ID (Yazar sirasina göre / by author order) & \\
\hline (D) orcid.org/0000-0001-5339-6537 (D) orcid.org/0000-0002-6543-7663
\end{tabular}

*Sorumlu Yazar/Corresponding Author: m.acikgoz76@hotmail.com.tr

Öz: Bu çalışma, 2015-2016 yıllarında Iğdır, Ağrı ve Van illeri (Türkiye) hububat alanlarında Süne Eurygaster spp. (Hemiptera: Scutelleridae)'nin yumurta parazitoiti Trissolcus Ashmead, 1893 (Hymenoptera: Scelionidae) türlerini belirlemek amacıyla yürütülmüştür. Süne yumurta paketleri zararlının yoğun olarak görüldüğü hububat ekiliş alanlarında toplanmıştır. Toplanan Süne yumurtaları plastik tüp içerisine konularak $25 \pm 1{ }^{\circ} \mathrm{C}$ sıcaklık ve $\% 65 \pm 5$ nem ortamında kültüre alınmıştır. Çalışma sonucunda, Süne yumurta parazitoitleri olarak; Trissolcus grandis (Thomson, 1860), T. vassilievi (Mayr, 1879), Telenomus chloropus (Thomson, 1861) (Scelionidae) ve Ooencyrtus sp. (Encyrtidae) türleri belirlenmiştir. Ağrı'dan toplanan yumurta paketlerinden Trissolcus grandis; Iğdır'dan toplanan yumurta paketlerinden Trissolcus grandis, T. vassilievi, Ooencyrtus sp. ve Telenomus chloropus; Van'dan ise Trissolcus grandis ve T. vassilievi türleri tespit edilmiştir. Tespit edilen türlerin popülasyonu içerisindeki dağılımları ise; Trissolcus grandis $\% 56$, Telenomus chloropus $\% 22$, T. vassilievi $\% 10$ ve Ooencyrtus sp. ise \% 12 oranlarında gözlemlenmiştir. Çalışmanın yürütüldüğü illerde en yaygın türün T. grandis olduğu tespit edilmiştir.

Anahtar Kelimeler: Süne, doğal düşman, tahıl, Iğdır, Ağrı, Van

\section{Studies on Egg Parasitoid, Trissolcus (Hymenoptera: Scelionidae) Species of Sunn pest Eurygaster spp. in Cereal Planting Areas: Iğdır, Ağrı and Van Provinces, Turkey}

\begin{abstract}
This study aimed to determine the egg parasitoids Trissolcus Ashmead, 1893 (Hymenoptera: Scelionidae) species of Sunn pest (Eurygaster spp. Hemiptera: Scutelleridae), in cereal areas of Ağrı, Iğdır and Van provinces in the years 20152016. Sunn pest egg packages were collected in the grain cultivation areas where the pest is common. Collected eggs were placed in a plastic tube and cultured at $25 \pm 1{ }^{\circ} \mathrm{C}$ and $65 \pm 5 \%$ humidity. As a result of the study, Sunn pest as egg parasitoid; Trissolcus grandis (Thomson, 1860), T. vassilievi (Mayr, 1879), Telenomus chloropus (Thomson, 1861) (Scelionidae) and Ooencyrtus sp. (Encyrtidae) species were determined. T. grandis parasitoid species were identified from the egg samples taken from Ağrı, while Trissolcus grandis, T. vassilievi, Ooencyrtus sp. and Telenomus chloropus were identified from the samples taken from Iğdır, and T. grandis and T. vassilievi were identified from the samples taken from Van. The distribution rates of the detected species within the population were; Trissolcus grandis $56 \%$, Telenomus chloropus $22 \%$, Trissolcus vassilievi $10 \%$, and Ooencyrtus sp. $12 \%$. It was determined that the most common species in the provinces where the study was conducted was T. grandis.
\end{abstract}

Keywords: Sunn pest, natural enemy, grain, Iğdır, Ağrı, Van

\footnotetext{
": Bu çalışma, Iğdır Üniversitesi, Fen Bilimleri Enstitüsü tarafından kabul edilen birinci yazara ait "Iğdır ve Çevre İllerinde Tahıl Ekiliş Alanlarındaki Eurygaster Laporte, 1832 türleri (Hemiptera: Scutelleridae), Zarar Durumları ve Doğal Düşmanlarının Belirlenmesi” isimli Yüksek Lisans Tez çalışmasının bir bölümünden üretilmiştir.
} 


\section{Giriș}

Tahıl, insan ve hayvan gıdası olarak önemli bir yere sahiptir. Çoğu ülkelerde olduğu gibi Türkiye'de üretilen tahıllar içerisinde buğday ilk sırayı almaktadır. Türkiye'de, 2019 yılı verilerine göre, buğday ekiliş alanı 68.5 milyon da ve üretim miktarı 19 milyon ton olup; Doğu Anadolu Bölgesi 6 . milyon da ekiliş alanıyla \% 8.75 ve 1 . milyon ton üretim ile \% 5.26'lık bir paya sahiptir. Doğu Anadolu Bölgesi'nde yer alan Ağrı, Iğdır ve Van illerinde; sirasiyla 897 bin da (\% 14.82), 202 bin da (\% 3.33) ve 617 bin da (\% 10.21) ekiliş alanında sirasiyla, 109 bin ton (\% 10.29), 39 bin ton (\% 3.71) ve 72 bin ton $\left(\begin{array}{ll}\% & 6.82\end{array}\right)$ buğday üretimi gerçekleştirilmiştir (Anonim, 2021).

Süne, Eurygaster spp. (Hemiptera: Scutelleridae) buğday verim ve kalitesini etkileyen en önemli zararlılardandır. Bu zararlı ilk defa, 19271929 y1llarında Güney Anadolu, 1939-1941 yıllarında ise Güneydoğu Anadolu'da salgın yapmıştır. Sünenin tanedeki emgi oranının protein miktarına ve buğday çeşidine bağlı olarak değiştiği, \% 3-5 emgi olduğunda buğdayın ekmeklik, makarnalık ve tohumluk özelliklerinin kısmen veya tamamen kaybettiği belirtilmiştir (Yüksel, 1969; Rumyantseva, 1981; Lodos, 1986; Memişoğlu ve Özer, 1994; Güllü ve Kanat, 2011). Süne salgınlarıyla mücadelede en çok kimyasal preparatlar tercih edilmiştir. Ancak, bu kimyasalların hedef dışı alanlara ulaşmasıyla birlikte çevreye vermiş olduğu zararlardan dolayı alternatif mücadele yöntemlerinin arayış1 başlamıştır. $\mathrm{Bu}$ yöntemler içerisinde yumurta parazitoitleri Trissolcus (Ashmead, 1893) önem kazanmıştır (Lodos, 1961, 1986; Yüksel, 1968; Melan, 1994; Memişoğlu ve Özer, 1994; Şimşek ve ark., 1994; Babaroğlu, 2006; Gözüaçık ve Yiğit, 2012; Kodan ve Gürkan, 2016). Türkiye'nin bazı bölgelerinde Süne yumurta parazitoitlerinin etkinliğinin \% 100'e varan oranlarda olduğu, Süne popülasyonunu Ekonomik Zarar Eşiği (EZE) altında tutabildiği belirtilmiştir (Zwölfer, 1942; Lodos, 1961; Şimşek ve Sezer, 1985; Memişoğlu ve Özer, 1994; Öncüer ve Kıvan, 1995; Şimşek, 1999; Tarla ve Kornoşor, 2003; İslamoğlu ve ark., 2008; Kodan ve Gürkan, 2016; Gözüaçık ve Yiğit, 2020).

Türkiye'de bugüne kadar yapılan çalışmalarda Trissolcus (18), Telenomus (1), Gryon (1) ve Ooencyrtus (2) cinslerine bağlı 22 Süne yumurta parazitoit türü tespit edilmiştir. Bunlardan, Güneydoğu Anadolu Bölgesi'nde 15 (Yüksel, 1968; Çatalpınar, 1972; Şimşek ve Yaşarakıncı, 1986; Öncüer, 1991; Koçak ve Kılınçer, 2001; Tarla ve Kornoşor, 2003; Güllü ve Koçak, 2011; Gözüaçık ve ark., 2013), Akdeniz Bölgesi'nde 15 (Zwölfer, 1942; Çatalpınar, 1972; Şimşek ve Sezer,
1985; Şimşek ve ark., 1994; Tarla, 1997; Koçak ve Kılınçer, 2000; Koçak ve Kılınçer, 2001; Çolak, 2004), Marmara Bölgesi'nde 15 (Akınc1 ve Soysal, 1992; Öncüer ve Kıvan, 1995; Melan, 1994; Koçak ve K1lınçer, 2001; Çetin ve ark., 2009; Atak, 2012), İç Anadolu Bölgesi'nde 12 (Öncüer, 1991; Memişoğlu ve Özer, 1994; Koçak ve Kılınçer, 2000; Koçak ve Kılınçer, 2001; Babaroğlu, 2006; Kodan ve Gürkan, 2016), Ege Bölgesi'nde 9 (Öncüer, 1991; Koçak ve Kılınçer, 2001; Polat, 2005; Zengin ve Karaca, 2018), Karadeniz Bölgesi'nde 3 (Koçak ve Kılınçer, 2001) ve Doğu Anadolu Bölgesi'nde 4 (Öncüer, 1991; Koçak ve Kilınçer, 2001; Alaserhat ve Canbay, 2018) tür olduğu saptanmıştır.

Süne yumurta parazitoitlerinden Trissolcus semistriatus'un baskın tür olduğu ve bu türü sirasiyla $T$. simoni, $T$. grandis, $T$. vassilievi, T. pseudoturesis, T. rufiventris, T. djadetshko ve T. manteroi türlerinin izlediği bildirilmiştir (Koçak ve Kılınçer, 2001; Koçak ve ark., 2007). Bölgelere göre dağılımları incelendiğinde, Trissolcus semistriatus ve $T$. grandis Türkiye'nin bütün bölgelerinde; T. simoni Doğu ve Güneydoğu Anadolu bölgeleri hariç diğer bütün bölgelerde; T. vassilievi İç Anadolu, Akdeniz, Doğu ve Güneydoğu Anadolu bölgelerinde; T. pseudoturesis İç Anadolu, Akdeniz, Ege ve Marmara bölgelerinde; T. rufiventris İç Anadolu ve Güneydoğu Anadolu bölgelerinde; T. djadetshko İç Anadolu ve Akdeniz bölgelerinde ve T. manteroi'nin ise; İç Anadolu Bölgesi'nde bulunduğu belirlenmiştir (Koçak ve Kılınçer, 2001).

Bu çalışma; Türkiye'nin Doğu Anadolu Bölgesi'ndeki Iğdır, Ağrı ve Van illeri hububat ekim alanlarında Süne (Eurygaster spp.)'nin doğal düşmanı olan yumurta parazitoiti, Trissolcus türleri ve popülasyon içerisindeki dağılımlarını belirlemek amacıyla ele alınmıştır.

\section{Materyal ve Yöntem}

Araştırma; Iğdır, Ağrı ve Van ili hububat ekiliş alanlarındaki Süne yumurta parazitoitlerini tespit etmek amacıyla 2015-2016 yılları Nisan ve Ağustos ayları arasında yürütülmüştür. $\mathrm{Bu}$ kapsamda Iğdır'da Aralık, Merkez, Karakoyunlu ve Tuzluca ilçelerine bağlı 57 köy, Ağrı'da Doğubayazıt, Diyadin, Eleșkirt, Hamur, Merkez, Taşlıçay, Tutak ve Patnos ilçelerine bağlı 29 köy ve Van'da Başkale, Çaldıran, Edremit, Erciş, İpekyolu, Muradiye, Özalp, Saray ve Tuşba ilçelerine bağll 27 köy olmak üzere Süne zararlısının yoğun olarak görüldüğü hububat ekiliş alanlarındaki toplam 21 ilçeye bağlı 113 tarlada yumurta paketleri toplanmıştır (Şekil 1a). Süne yumurtalarından 

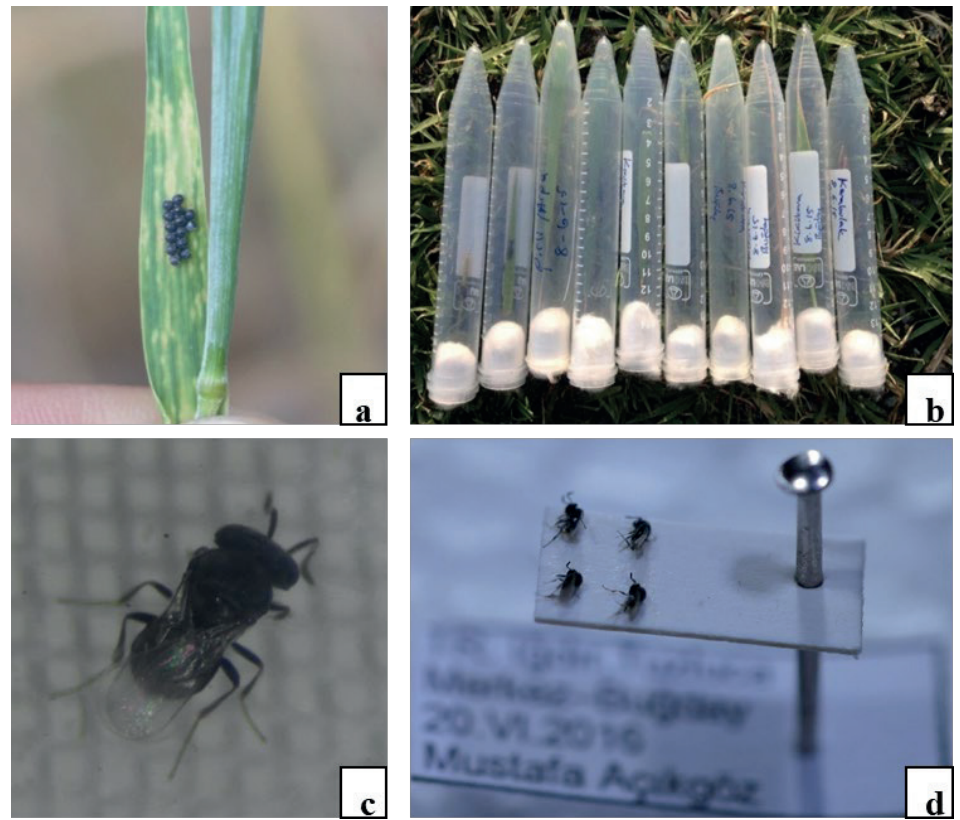

Şekil 1. Parazitli Süne yumurta paketi (a), her birinin ayrı ayrı kültüre alınması (b), parazitoit ergini çıkışı (c) ve teşhise hazır hale getirilmesi (d)

Figure 1. Parasitic Sunn pest egg package (a), culturing each one separately (b), the emergence of parasitoid adults (c), and preparation for diagnosis (d)

parazitoit elde etmek için yumurta paketlerinin her biri plastik tüp $(1.5 \mathrm{~cm} \times 12 \mathrm{~cm})$ içerisine bırakılmış, ağzı pamukla kapatılmış ve tüp üzerine gerekli etiket bilgileri yazılarak kültüre alınmıştır (Şekil 1b). Daha sonra yumurta paketleri laboratuvara getirilerek $25 \pm 1{ }^{\circ} \mathrm{C}$ sicaklik ve $\% \quad 65 \pm 5$ nem ortamında yumurta parazitoitleri çıkıncaya kadar bekletilmiştir (Şekil 1c). Parazitli yumurtalardan çıkan erginler, öldükten sonra teşhis için \% 70’lik etil alkol içerisinde muhafaza edilmiştir. Bu farklı tüplerdeki parazitoitler daha sonra teşhis edilmek üzere küçük dikdörtgen $(0.5 \times 1 \mathrm{~cm})$ kartonlara parazitoitin thorax'ının sağ tarafından (şeffaf bir yapışkan yardımıyla) yapıştırılıp teşhise hazır hale getirilmiştir (Şekil 1d). Yumurta parazitoitlerinin teşhisi; Süleyman Demirel Üniversitesi, Ziraat Fakültesi, Biyoteknoloji Bölümü Öğretim Üyesi Prof. Dr. Erhan KOÇAK tarafından yapılmıştır.

\section{Bulgular ve Tartışma}

Iğdır, Ağrı ve Van illeri hububat ekiliş alanlarından 99 parazitlenmiş Süne yumurta paketi toplanmış ve Süne yumurta parazitoitleri olarak Trissolcus grandis (Thomson, 1861), T. vassilievi (Mayr, 1879), Telenomus chloropus (Thomson, 1861) (Hymenoptera: Scelionidae) ve Ooencyrtus sp. (Hymenoptera: Encyrtidae) türleri belirlenmiştir. $\mathrm{Bu}$ türlerin çalışmanın yapıldığ 1 illerdeki dağılımları ise, Ağrı'da T. grandis, Iğdır'da T. grandis, T. vassilievi, Telenomus chloropus, Ooencyrtus sp., Van ilinde T. grandis ve
T. vassilievi bulunmuştur (Tablo 1). Koçak ve ark. (2014), Doğu Anadolu Bölgesi’nin Malatya, Elazı ̆̆ ve Ağrı illeri hububat alanlarında Trissolcus semistriatus, T. grandis, $T$. vassilievi ve T. culturatus türlerini belirlerken; Alaserhat ve Canbay (2018) ise, Ağrı'da sadece T. grandis'i tespit etmişlerdir. Ağrı'da tespit edilen tür ile bu çalışma ile elde edilen tür benzerlik göstermektedir. Iğdır ve Van illerinde elde edilen türler ise ilk defa bu çalışmayla ortaya konulmuştur.

Her 3 ilde, Süne yumurta paketlerinden elde edilen parazitoitlerin 59'u T. grandis, 23'ü Telenomus chloropus, 13'ü Ooencyrtus sp. ve 11'i T. vassilievi olduğu belirlenmiştir (Tablo 1).

Tespit edilen parazitoit popülasyonu içerisindeki türlerin dağılımları ise, T. grandis $\%$ 56, Telenomus chloropus \% 22, T. vassilievi $\%$ 10; Encyrtidae familyasından Ooencyrtus sp. ise \% 12 oranlarında bulunmuştur. Bunlardan en yaygın türün Ağrı ve Iğdır illerinde $T$. grandis'in Van ilinde ise T. grandis ve T. vassilievi'nin olduğu tespit edilirken; Trakya Bölgesi'nde $T$. grandis'in (Akınc1 ve Soysal, 1992), Hatay (Tarla, 1997), Ankara, Konya (Kodan, 2007), Adiyaman ve Diyarbakır illerinde (Gözüaçık ve ark., 2013) T. semistriatus'un, Şanlıurfa ilinde ise T. vassilievi'nin (Gözüaçık ve ark., 2013) en yaygın tür olduğu kaydedilmiştir.

Çalışmalarda parazitoit türlerinin her birinin belirli mikro-klimaları tercih ettikleri gözlenmiş ve 
Tablo 1. Ağrı, Iğdır ve Van illeri hububat ekim alanlarında 2015 ve 2016 yıllarında tespit edilen Süne yumurta parazitoit türlerinin dağılımı, sayısı ve yumurta paketi sayısı

Table 1. Distribution, number and number of egg packs of Sunn pest egg parasitoid species detected in the grain cultivation areas of Ağrı, Iğdır and Van provinces in 2015 and 2016

\begin{tabular}{|c|c|c|c|c|c|}
\hline İl & İlçe & Tarih & Köyler & $\begin{array}{c}\text { Yumurta } \\
\text { paket say1s1 }\end{array}$ & Saptanan türler \\
\hline Ağr1 & Merkez & 16.06 .2015 & Yolugüzel & 2 & Trissolcus grandis \\
\hline \multirow{41}{*}{ Iğdır } & Aralik & 26.06 .2016 & Aşağ1 Çiftlik & 2 & Telenomus chloropus \\
\hline & Karakoyunlu & 19.06.2016 & Gökçeli & 1 & Telenoтиs chloropus \\
\hline & \multirow{12}{*}{ Merkez } & 25.06 .2016 & Çilli (2) & \multirow{4}{*}{7} & \multirow{4}{*}{ Trissolcus grandis } \\
\hline & & 11.06 .2016 & Kasimcan (1) & & \\
\hline & & 24.06 .2016 & Taşlıca (3) & & \\
\hline & & 10.06 .2015 & Hakmehmet (1) & & \\
\hline & & 11.06 .2016 & Özdemir (2) & \multirow{5}{*}{6} & \multirow{5}{*}{ Telenomus chloropus } \\
\hline & & 25.05 .2016 & Kuzugüden (1) & & \\
\hline & & 04.06 .2015 & Kasimcan (1) & & \\
\hline & & 10.06 .2015 & Hakmehmet (1) & & \\
\hline & & 10.06 .2015 & Özdemir (1) & & \\
\hline & & 24.06 .2016 & Taşlica & 2 & Ooencyrtus sp. \\
\hline & & 19.06 .2016 & Sarıçoban (1) & \multirow{2}{*}{3} & \multirow{2}{*}{ Trissolcus vassilievi } \\
\hline & & 24.06 .2016 & Taşlica (2) & & \\
\hline & \multirow{27}{*}{ Tuzluca } & $13-20.06 .2016$ & Gaziler (3) & \multirow{14}{*}{48} & \multirow{14}{*}{ Trissolcus grandis } \\
\hline & & 12.06 .2015 & Gaziler (3) & & \\
\hline & & 27.05 .2016 & Eğrekdere (3) & & \\
\hline & & 05-20.06.2016 & Eğrekdere (5) & & \\
\hline & & 17.06 .2015 & Eğrekdere (2) & & \\
\hline & & 05-20.06.2016 & Küçükova (12) & & \\
\hline & & 08.06 .2015 & Küçükova (5) & & \\
\hline & & 24.05 .2016 & Küçükova (1) & & \\
\hline & & 09.06 .2015 & Üç kaya (1) & & \\
\hline & & 08.06 .2015 & Karabulak (4) & & \\
\hline & & 20.06 .2016 & Merkez (1) & & \\
\hline & & 05.06 .2016 & Pirli (5) & & \\
\hline & & 08.06 .2015 & Pirli (2) & & \\
\hline & & 12.06 .2015 & Ağabey (1) & & \\
\hline & & 20.06 .2016 & Gaziler (4) & \multirow{5}{*}{11} & \multirow{5}{*}{ Ooencyrtus sp. } \\
\hline & & $20-30.06 .2016$ & Eğrekdere (2) & & \\
\hline & & 30.06 .2016 & Küçükova (2) & & \\
\hline & & 03.07 .2016 & Ínce (2) & & \\
\hline & & 08.07 .2015 & Eğrekdere (1) & & \\
\hline & & 03.07 .2016 & Ali Köse (3) & \multirow{2}{*}{6} & \multirow{2}{*}{ Trissolcus vassilievi } \\
\hline & & 20.06 .2016 & Küçükova (3) & & \\
\hline & & 20.06 .2016 & Gaziler (2) & \multirow{6}{*}{14} & \multirow{6}{*}{ Telenomus chloropus } \\
\hline & & $09-30.06 .2015$ & Üç Kaya (6) & & \\
\hline & & 20.06.2016 & Üç Kaya (3) & & \\
\hline & & 30.06 .2016 & Küçükova (1) & & \\
\hline & & 27.05 .2016 & Turabi (1) & & \\
\hline & & 20.06 .2016 & Buruksu (1) & & \\
\hline \multirow{3}{*}{ Van } & Tuşba & 14.06 .2016 & Çakırbey & 1 & Trissolcus vassilievi \\
\hline & \multirow{2}{*}{ İpekyolu } & 15.06 .2016 & Kaymaklı & 1 & Trissolcus vassilievi \\
\hline & & 15.06 .2016 & Irgat & 2 & Trissolcus grandis \\
\hline
\end{tabular}

yoğun olarak bulunan $T$. grandis'in daha çok kuru ve az sicak alanları, Telenomus chloropus'un ise soğuk ve nemli ortamları tercih ettiği görülmüştür. Areshnikov ve ark. (1987), Ukrayna'nın güney bölgelerindeki kuru-1lık ortamın T. grandis için, soğuk-nemli iklimlerin ise T. chloropus için daha uygun olduğunu, sulak alanlarda parazitoitlerde fekonditenin çok daha fazla olmasından dolayı bu alanlarda Süne popülasyonu üzerinde daha etkili olduklarını belirtmişlerdir.

Ağrı'da bulunan hububat tarlalarında Sünenin yoğun olarak bulunduğu yerlerde Süne yumurta paketleri aranmış sadece Ağrı Merkez ilçesi Yolugüzel köyünde 2 paket Süne yumurtasından T. grandis elde edilmiştir. Van'da bulunan hububat 
tarlalarında Sünenin yoğun olarak bulunduğu yerlerde Süne yumurta paketleri aranmış Tuşba ilçesi Çakırbey köyünde 1 adet Süne yumurta paketinden Trissolcus vassilievi, İpekyolu ilçesi Kaymaklı köyünde 1 adet Süne yumurta paketinden T. vassilievi, Irgat köyünde ise 2 adet Süne yumurta paketinden $T$. grandis elde edilmiştir. Iğdır'da Sünenin yoğun olarak bulunduğu buğday tarlalarında Süne yumurta paketleri aranmış ve Aralık'ta 2, Karakoyunlu'da 1, Merkez'de 18 ve Tuzluca ilçesinde 79 Süne yumurta paketlerinden parazitoitler elde edilmiştir (Tablo 1). Ağrı ve Van illerinde bulunan hububat alanlarında Süne popülasyonunu düşük olduğundan yeteri kadar Süne yumurta paketi toplanamamıştır.

İllerden toplanan yumurta paketlerinden $\%$ 7.07'sinde (7 yumurta paketi) farklı iki tür teșhis edilmiştir. Bunlar; 3 yumurta paketinden Ooencyrtus sp. + Telenomus chloropus, 2 yumurta paketinden Ooencyrtus sp. + T. grandis, 1 yumurta paketinden $T$. vassilievi + Ooencyrtus sp., 1 yumurta paketinden $T$. vassilievi $+T$. grandis elde edilmiştir. Tek bir yumurta paketinden en çok bulunma oranının Ooencyrtus sp. ile Telenomus chloropus arasında meydana geldiği belirlenmiştir. Remaudière ve Skaf (1963), Suriye'de parazitlenmiş Süne yumurtalarından çoğunlukla tek bir parazit türü, bazen 2 veya nadir olarak 3 tür de çıktığını saptamıştır. Koçak ve Kılınçer (2002), yapmış olduğu çalışmada, parazitlenmiş Süne yumurta paketinde iki farklı Trissolcus türü elde etmiş; toplam olarak beş türü ( $T$. semistriatus, $T$. grandis, T. simoni, $T$. vassilievi ve $T$. pseudoturesis) tek bir yumurta paketinde ikişerli olarak saptamıştır. Aynı çalışmada araştırmacı, Trissolcus semistriatus diğer dört tür ile $T$. grandis, T. pseudoturesis ve T. vassilievi türlerinin ise sadece $T$. simoni ve $T$. semistriatus ile aynı yumurta paketinde bulunduğunu ve tek bir yumurta paketinde en yüksek bulunma oranının $T$. simoni ile T. semistriatus arasında olduğunu ifade etmiştir.

\section{Sonuçlar}

Sonuç olarak, Ağrı ve Iğdır illerinde baskın tür $T$. grandis olmuş, Van ilinde ise T. grandis ve T. vassilievi eşit sayıda elde edilmiştir. Türkiye genelinde baskın tür olan T. semistriatus'a Iğdır, Ağrı ve Van illerinde rastlanılmamıştır; ancak, diğer yaygın tür olan $T$. grandis 3 ilde tespit edilmiştir. Doğu Anadolu Bölgesi'nde Süne yumurta parazitoiti olarak Telenomus chloropus ve Ooencyrtus sp. ilk defa bu çalışmayla elde edilmiştir. Sünenin doğal düşmanlarının yaşam alanlarının korunması ve iyileştirilmesi, Iğdır, Ağrı ve Van illerinde Süneye karşı yürütülecek mücadele çalışmalarında fayda sağlayacaktır.

\section{Kaynaklar}

Akıncı, A.R., Soysal, A., 1992. Trakya Bölgesi'nde Süne (Eurygaster spp.)'nin yumurta parazitoitleri ve etkinlikleri üzerinde araștırmalar. Uluslararası Entegre Zirai Mücadele Sempozyumu, 15-17 Ekim, Ankara, s. 258

Alaserhat, İ., Canbay, A., 2018. Ağr1 ilinde hububat alanlarında zararlı Süne, Eurygaster integriceps Put. (Hemiptera: Scutelleridae) ve yumurta parazitoiti Trissolcus grandis (Thom.) (Hymenoptera: Scelionidae)'in yayılış alanları. Harran Tarım ve Gida Bilimleri Dergisi, 22(3): 413-419.

Anonim, 2021. Bitkisel Üretim İstatistikleri. Türkiye İstatistik Kurumu, (http://www.tuik.gov.tr/UstMenu. do?metod=temelist), (Erișim tarihi: 23.11.2021).

Areshnikov, B.A., Melnikova, G.L., Sekun, N.P., 1987. Egg parasites (Hymenoptera: Scelionidae) under the conditions of irrigation of the south of the steppe zone of the Ukraine and their role in the abundance dynamics of the Sunn pest Eurygaster integriceps Put. (Heteroptera: Scutelleridae). Entomologi Cheskoe Obozrenie, 66(1): 47-51.

Atak, Ş., 2012. Kocaeli ilinde Süne Eurygaster spp. (Hemiptera: Scutelleridae) yumurta parazitoitleri (Hymenoptera: Scelionidae) ve etkinlikleri. Yüksek lisans tezi, Kocaeli Üniversitesi Fen Bilimleri Enstitüsü, Kocaeli.

Babaroğlu, N.E., 2006. Süne [Eurygaster spp. (Hemiptera: Scutelleridae)] mücadelesinde kullanılan bazı ilaçların Orta Anadolu Bölgesi'nde Süne yumurta parazitoitleri Trissolcus spp. (Hymenoptera: Scelionidae)'ne etkileri üzerine araştırmalar. Doktora tezi, Ankara Üniversitesi Fen Bilimleri Enstitüsü, Ankara.

Çatalpınar, A., 1972. Güney ve Güneydoğu Anadolu'da Süne yumurta parazitleri üzerinde sürvey çalışmaları. Zirai Mücadele Araştırma Y1llığ , Ankara, 121: 190191.

Çetin, G., Koçak, E., Hantaş, C., 2009. Güney Marmara Bölgesi hububat ekosistemindeki Hemipterler ve yumurta parazitoitleri üzerine bir çalışma, Türkiye III. Bitki Koruma Kongresi, 15-18 Temmuz, Van, s. 323.

Colak, A.E., 2004. Buğdayda farklı Süne (Eurygaster integriceps Put.) (Heteroptera: Scutelleridae) yoğunluklarının verime ve parazitoitlerinin Süne popülasyonuna etkisinin belirlenmesi. Yüksek lisans tezi, Çukurova Üniversitesi Fen Bilimleri Enstitüsü, Adana.

Gözüaçık, C., Yiğit, A., 2012. Süne, Eurygaster integriceps Put. (Hemiptera: Scutelleridae) yumurta parazitoiti, Trissolcus semistriatus Nees (Hymenoptera: Scelionidae)'un konukçu tercihleri. Türkiye Biyolojik. Mücadele Dergisi, 3(2): 145-156.

Gözüaçı, C., Yiğit, A., 2020. Adıyaman ilinde farklı ekosistemlerdeki hububat alanlarında yumurta paraziotiti (Trissolcus spp.)'nin Süne, Eurygaster integriceps Put. (Heteroptera: Scutelleridae) popülasyonu üzerindeki etkinliği. Uluslararası Tarım ve Yaban Hayatı Bilimleri Dergisi, 6(1): 55-65. 
Gözüaçık, C., Yiğit, A., Yücel A., 2013. Adıyaman, Diyarbakır ve Şanlıurfa illeri buğday tarlalarında Süne, Eurygaster integriceps Put. (Hemiptera: Scutelleridae)'in yumurta parazitoitleri ve popülasyon içerisindeki dağılımları GAP Biyoçeşitlilik Sempozyumu, 23-25 Mayıs, Şanlıurfa, s. 18.

Güllü, M., Kanat, A.D., 2011. Süne, Eurygaster integriceps Put. (Hemiptera: Scutelleridae) emgisinin golia ekmeklik buğday çeşidinin biyolojik değerlerine etkisi. Türkiye IV. Tohumculuk Kongresi, 14-17 Haziran, Samsun, s. 24-27.

Güllü, M., Koçak, E., 2011. Türkiye faydalı böcek faunası için yeni bir kayit: Trissolcus nigribasalis (Voegelé) (Hymenoptera: Scelionidae). Türkiye IV. Bitki Koruma Kongresi, 28-30 Haziran, Kahramanmaraș, s. 457.

İslamoğlu, M., Kornoşor, S., Tarla, Ş., 2008. Süne yumurta parazitoidi Trissolcus semistriatus (Hymenoptera: Scelionidae)'un kitle üretimi ve salım alanlarında etkinliğinin belirlenmesi. Ülkesel Tahıl Sетровуити, 2-5 Haziran, Konya, s. 921-931.

Koçak, E., Bilginturan, S., Kaya, E., Gözüaçık, C., Babaroğlu, N.E, İslamoğlu, M., Çetin, G., Tülek, A., 2014. Türkiye hububat alanlarındaki Süne (Eurygaster spp.) türlerinin dağıllmı. Türkiye V. Bitki Koruma Kongresi, 3-5 Şubat, Antalya, s. 115.

Koçak, E., Çetin, G., Hantaş, C., 2007. Güney Marmara Bölgesi hububat alanlarındaki Eurygaster (Heteroptera: Scutelleridae) türleri ve mücadele durumunun değerlendirilmesi. Türkiye II. Bitki Koruma Kongresi, 27-29 Ağustos, Isparta, s. 75.

Koçak, E., Kılınçer, N., 2000. Türkiye faydalı faunası için yeni kayıt Trissolcus (Hym: Scelionidae) türleri. Bitki Koruma Bülteni, 40(3-4): 169-177.

Koçak, E., Kılınçer, N., 2001. Türkiye Süne [Eurygaster spp. (Het.: Scutelleridae)] yumurta parazitoidi Trissolcus (Hym.: Scelionidae) türleri. Bitki Koruma Bülteni, 41(3-4): 167-181.

Koçak, E., Kılınçer, N., 2002. Süne Eurygaster spp., (Het: Scutelleridae)'nin aynı yumurta paketinin Trissolcus (Hym.: Scelionidae) türleri tarafından parazitlenme durumu. Bitki Koruma Bülteni, 42(1-4): 23-24.

Kodan, M., 2007. Yumurta parazitoidi Trissolcus (Hymenoptera: scelionidae) türlerinin Orta Anadolu bölgesinde biyolojisi üzerinde araştırmalar. Doktora tezi, Ankara Üniversitesi Fen Bilimleri Enstitüsü, Ankara.

Kodan, M., Gürkan, M.O., 2016. Orta Anadolu Bölgesi'nde parazitoit Trissolcus (Hym.: Scelionidae) türlerinin popülasyon değişimi ve konukçusu Süne [Eurygaster spp. (Hem: Scutelleridae)] ile ilişkileri. Bitki Koruma Bülteni, 56(1): 29-47.

Lodos, N., 1961. Türkiye, Irak, İran ve Suriye'de Süne (Erygaster integriceps Put.) problemi üzerine araştırmalar. Ege Üniversitesi Ziraat Fakültesi Yayınlarl, Ege Üniversitesi Matbaas1, No: 51, İzmir.
Lodos, N., 1986. Türkiye Entomolojisi-II, Genel Uygulamalı ve Faunistik. Ege Üniversitesi Bitki Koruma Bölümü, Ege Üniversitesi Matbaası, İzmir.

Melan, K., 1994. Trakya Bölgesi'nde Süne türleri ve Süne yumurta parazitoitleri, III. Biyolojik Mücadele Kongresi, 25-28 Ocak, İzmir, s. 147-154.

Memişoğlu, H., Özer, M., 1994. Ankara ilinde Avrupa Sünesi (Eurygaster maura L., (Hemiptera: Scutelleridae)'nin doğal düşmanları ve etkinlikleri. Türkiye III. Biyolojik Mücadele Kongresi, 25-28 Ocak, İzmir, s. 575.

Öncüer, C., 1991. Türkiye bitki zararlısı böceklerinin parazit ve pradatör kataloğu. Ege Üniversitesi Ziraat Fakültesi Yayınları, No: 505, İzmir.

Öncüer, C., Kıvan, M., 1995. Tekirdağ ve çevresinde Eurygaster (Heteroptera: Scutelleridae) türleri, tanımları, yayılışları ve bunlardan Eurygaster integriceps Put.'in biyolojisi ve doğal düşmanları üzerinde araștırmalar. Türk Tarım ve Ormancllık Dergisi, 19(4): 223-230.

Polat, E., 2005. Aydın ve çevresinde Eurygaster Heteroptera: Scutelleridae) türleri, tanımları, yaşayışları, doğal düşmanları üzerinde araştırmalar. Yüksek lisans tezi, Adnan Menderes Üniversitesi Fen Bilimleri Enstitüsü, Aydın.

Remaudiere, G., Skaf, R., 1963. Analyse du complexe des Hymenopteres parasites oophages d' Eurygaster integriceps Put. [Het. Pentatomidae] en Syrie. Revue de Pathologie vegetale et De Entomologie Agricole de France, 42(1): 15-25.

Rumyantseva, V.I., 1981. Economic threshold of injuriousness of the most important pests of cereal crops. Zashchita Rastenii, 12: 10-11. (In Russian).

Simşek, N., Sezer, A.C., 1985. Hatay ilinde buğdayda Süne (Eurygaster integriceps Put.)'nin yumurta ve nimf popülasyonu ile zararı üzerinde ön çalışmalar. Bitki Koruma Bülteni, 25(1-2): 30-48.

Şimşek, Z., 1999. Sivrihisar (Eskişehir)'da hububat ekilişlerinde Avrupa Süne'si (Eurygaster maura L.) ile yumurta parazitoiti Trissolcus semistriatus Nees'nin popülasyon gelișmesi, Türkiye IV. Biyolojik Mücadele Kongresi, 26-29 Ocak, Adana, s. 107-120.

Şimşek, Z., Güllü, M., Yaşarbaş, M., 1994. Akdeniz Bölgesi'nde Süne (Eurygaster integriceps Put.)'nin doğal düşmanları ve etkinlikleri üzerinde araștırmalar. Türkiye III. Biyolojik Mücadele Kongresi, 25-28 Ocak, İzmir, s. 155-164.

Şimşek, Z., Yaşarakıncı, N., 1986. Güneydoğu Anadolu Bölgesinde Süne yumurta parazitlerinin (Trissolcus spp.) etkinliği üzerinde rol oynayan faktörler. Türkiye 1. Biyolojik Mücadele Kongresi, 12-14 Şubat, Adana, s. 330-341.

Tarla, Ş., 1997. Antakya ve çevresinde Süne, Eurygaster integriceps Put. yumurta parazitoitlerinin tespiti ve bunların kitle üretim olanakları üzerinde araştırmalar. Yüksek lisans tezi, Mustafa Kemal Üniversitesi Fen Bilimleri Enstitüsü, Antakya.

Tarla, Ş., Kornoşor, S., 2003. Yumurta parazitoiti Trissolcus semistriatıls Nees (Hymenoptera: Scelionidae)'un Süne'nin biyolojik mücadelesinde salımı ve etkinliğinin değerlendirilmesi. Çukurova 
Üniversitesi Fen Bilimleri Enstitüsü Dergisi, 18(3): 69-78.

Yüksel, M., 1968. Güney ve Güneydoğu Anadolu'da Süne (Eurygaster integriceps Put.)'nin yay1lışı, biyolojisi, ekolojisi, epidemiolojisi ve zararı üzerinde araştırmalar. T.C. Tarım Bakanlığı, Zirai Mücadele ve Karantina Genel Müdürlüğü Yayınları, Teknik Bülten, Yeni Desen Matbaa, No: 46, Ankara.

Yüksel, M., 1969. Süne (Eurygaster integriceps Put.) zararı ve Kımıl (Aelia rostrata Boh.) zararıla mukayesesi üzerinde araștırmalar. Yeni Desen Matbaas1, Ankara. s. 64.
Zengin, E., Karaca, İ., 2018. Uşak ili buğday ekili alanlarda Süne [Eurygaster spp. (Hemiptera: Scutelleridae)] yumurtalarının parazitlenme oranları ile buğday tanelerindeki emgi oranları arasındaki ilişkinin belirlenmesi. Süleyman Demirel Üniversitesi Fen Bilimleri Enstitüsü Dergisi, 1: 221-225.

Zwölfer, W., 1942. Anadolu'nun Zararlı Direnlerinin Tanınması Üzerinde Etüd II., Süne, (Eurygaster integriceps Put.)'nin Epidemiyolojisi. Ziraat Vekaleti Neşriyatı Yayınları, Nebat Hastalıkları Serisi 10, Say1: 543, Ankara. 